\title{
Interpreting in mental health: Social, moral and spatial divisions of labor in health care for migrants
}

L'interprétariat en santé mentale: divisions sociale, morale et spatiale du travail dans les soins aux migrants

La interpretación en la salud mental: divisiones sociales, morales y espaciales en el trabajo de atención al migrante

\section{Anaïk Pian, Anne-Cécile Hoyez and Simona Tersigni}

\section{(2) OpenEdition}

12 Journals

Electronic version

URL: https://journals.openedition.org/remi/12095

DOI: $10.4000 /$ remi.12095

ISSN: $1777-5418$

This article is a translation of:

L'interprétariat en santé mentale : divisions sociale, morale et spatiale du travail dans les soins aux

migrants - URL : https://journals.openedition.org/remi/10768 [fr]

Publisher

Université de Poitiers

\section{Printed version}

Date of publication: 1 October 2018

ISBN: 979-10-90426-62-7

ISSN: 0765-0752

Electronic reference

Anaïk Pian, Anne-Cécile Hoyez and Simona Tersigni, "Interpreting in mental health: Social, moral and spatial divisions of labor in health care for migrants", Revue européenne des migrations internationales [Online], vol. 34 - $n^{\circ} 2$ et $3 \mid 2018$, Online since 01 January 2021, connection on 15 April 2022. URL: http://journals.openedition.org/remi/12095 ; DOI: https://doi.org/10.4000/remi.12095

This text was automatically generated on 15 April 2022.

(c) Université de Poitiers 


\section{Interpreting in mental health: Social, moral and spatial divisions of labor in health care for migrants}

L'interprétariat en santé mentale: divisions sociale, morale et spatiale du travail dans les soins aux migrants

La interpretación en la salud mental: divisiones sociales, morales y espaciales en el trabajo de atención al migrante

Anaïk Pian, Anne-Cécile Hoyez and Simona Tersigni

Translation : Jean-Yves Bart

1 In the mid-1980s, French medical handbooks identified three types of pathologies characterizing foreign patients. These were the so-called pathologies of importation, acquisition and adaptation to the host society - the latter category referring to mental disorders (Fassin, 2000). In this model taught to generations of physicians, the bodies of foreigners, perceived as 'carriers and passive receivers of diseases' (Ibid: 5), were associated with two risks: a risk of infection for the host society and a risk for the migrants themselves, as these diseases - particularly the mental disorders - were considered detrimental to their integration. French social scientists have been slow to address mental health among migrants (Cognet, Hamel, Sauvegrain, Gabarro, 2014), but several studies have helped deconstruct the culturalist visions that prevailed for a long time - and sometimes still have currency - in the medical community. At odds with approaches that point to culture and 'culture shock' as the explanation of mental disorders, these studies have documented the interplay between mental disorders and the conditions of migration (precariousness, isolation, discrimination, etc.) and emphasized the adverse effects of exile (Pestre, 2010; Veïsse et al., 2017) on mental health ${ }^{1}$.

2 Care for the migrant population - particularly those termed allophones in the current institutional terminology, meaning the non-French speakers $^{2}-$ still raises a fundamental issue these days: how can treatment be carried out when caregivers and 
patients do not share the same language? Indeed, orality and speech are crucial when it comes to identifying symptoms, making a diagnosis and providing care. Thus, the question of interpreting is a central one when it comes to health care in migration contexts.

3 Lack of interpreting contributes to social inequalities regarding health and access to health care. Several studies have noted that the language barrier is a major hindrance to somatic and mental health care (Kotobi, Larchanché, Kessar, 2013). It took a long time for professional interpreting to make headway into the health care community (Tabouri, 2009; Pian, 2014), despite recommendations made in national and European regulations. This difficult institutionalization should be related to the French Republican national context, ${ }^{3}$ which does not recognize minorities as such, and is accordingly reluctant to introduce specific provisions for them. However, professional interpreting is now at a pivotal juncture in the health care field. The new 'health' act of January 2016, ${ }^{4}$ whose implementing decree ${ }^{5}$ was published in May 2017, introduced measures for promoting health mediation and interpreting in public institutions, especially for those populations most removed from the health care system. Although these measures are neither binding nor funded, they support the efforts of non-profit groups that have been trying to have interpreting recognized as a core profession in the health care system. They also support the recommendations of the national plan for psychiatry and mental health (2011-2015) concerning the recourse to professional interpreting in the treatment of patients who speak little or no French.

4 Interpreting also poses a challenge where the etiology (Rhenter and Michel, 2010; Coldefy, 2016) of health care is concerned. The interpreter's presence disrupts the exclusive relationship between caregiver and patient, which is crucial in some psychiatric schools of thought. Conversely, other schools, such as ethnopsychiatry, even though it has been accused of not having fully done away with colonial thinking (Fassin, 2010), conceive the interpreter as a co-actor of health care. In France, since the early 1960s, interpreting has been a key concern for therapeutic practice in the Françoise Minkowska center (Bourdin and Larchanché, 2015). Other practitioners have pondered means to replicate the categories of semiological research and psychiatric therapy in sessions with Southeast Asian refugees defined as 'non-Francophone' by the psychiatric institution (Rechtman, 1992: 347). Beyond the debates on health care configurations in interpreting situations, the conception of the foreign patient as the Other is a broader debate, which relates to representations linked to the very history of medical professions and medical training in France. ${ }^{6}$

5 Since the 2000s, the economic and administrative precariousness of part of the 'migrant public" (Hachimi and Nacu, 2010; Défenseur des droits, 2016) has been of particular interest to psychiatrists (Chambon and Le Goff, 2016). In recent years, specialized publications (Cahiers du Rhizome, 2015; L'information psychiatrique, 2015a, 2015b, 2015c; Psychologie clinique, 2017) have investigated the need to provide tools for a clinical approach to exile as policies 'reshape and compromise intimacy', to the extent of requiring the 'reconstruction of a space for psychological interlocution between the individual and his or her therapists' (Piret and Douville, 2017: 6).

6 Against this background, this paper examines interpreting to investigate the social, moral and spatial division of labor in mental health care for migrants. ${ }^{8}$ The concept of 'social and moral division of labor', coined by Hughes (1958) and picked up by Payet (1997), refers to the imbalances, distributions and tensions in relationships between 
professionals working together in light of the tasks they are entrusted with and the ones that they effectively fulfill, and in light of their prestige and hierarchy. While the members of a profession have an interest in instilling the belief that their activity is a noble one, Hughes (1958) noted that they have to contend with less prestigious yet necessary tasks, which they often have to perform while being watched by others. The specificity of interpreting in mental health is that the relationship between patient and caregiver involves the mediation of an interpreter, who works both for the practitioner and for the patient.

7 Here, we adopt a multidisciplinary approach, combining sociology and geography, and this calls for extending the idea of a social and moral division of labor by paying attention to its spatial dimension. Indeed, professional practices involve issues that relates to the places where physicians work and where patients live. Thus, we will situate the spatial distribution of health care for migrants in different places in the two cities under study here, Rennes and Strasbourg. This approach, which calls for 'taking the contingency of socio-spatial configurations into consideration' (Bonny et al., 2012), allows us to draw on the emergence of localized dynamics to grasp social and political facts.

8 This paper is divided into three parts. Part 1 discusses the stakes of the professionalization of interpreting in the medical and social field, which is necessary to contextualize tensions identified in the social, moral and spatial division of health care. Part 2 shows how needs and uses (or lack thereof) or local interpreting resources by mental health institutions and professionals impact the health care landscape. Part 3 focuses on the dynamic of consultations, ${ }^{9}$ confronting the points of view of interpreters on their own practices with those of the psychiatrists and psychologists who rely on their services. By linking these dimensions, the paper ultimately sheds light on how interpreters, as new actors of health care, rearrange the configuration of care for migrants.

Box 1 : Methodology

The paper draws on fieldwork conducted in two French regional capitals: ${ }^{10}$ Strasbourg (Alsace) and Rennes (Brittany) and its inner suburbs. This choice has value in a number of ways beyond the mere fact that it allows us to look at cases that have been seldom studied. Indeed, Strasbourg and Rennes have been pioneers in terms of local initiatives for the development of professional interpreting. These initiatives have been promoted by the non-profit groups Migrations santé Alsace (MSA - Migrations health Alsace) in Strasbourg and Réseau Louis Guilloux (RLG - Louis Guilloux network) in Rennes. They both negotiated and forged partnerships with local authorities and health institutions (particularly the regional health agencies). Lastly, although Rennes and Strasbourg have distinct histories of migration (Alsace's is long, whereas Brittany's is more recent), they have both experienced changing migratory flows since the early 2000s. In particular, there have been increasing numbers of asylum seekers (and rejected asylum seekers) from the countries of the former Soviet bloc and Africa. Between 2014 and 2015 - according to the sources of the French Office for the Protection of Refugees and Stateless Persons (OFPRA) and the Ministry of the Interior, used in the statistical synthesis produced by the Regional Observatory of Integration and the City in 2017 for the Grand Est region - the number of permits granted for 
humanitarian reasons (refugees and beneficiaries of subsidiary protection status especially) has witnessed the sharpest increase, in comparison with permits granted for family reasons (37.6\%) or studying (34.2\%). In 2016, the Bas-Rhin (Alsace) department recorded 1634 first-time applications for asylum; Ille-etVilaine received 1724 (source: French office for Immigration and Integration, 2017). The latter number also indicates a rise in asylum applications in Brittany between 2012 and 2014, an average of 1200 new applications were submitted in the region. ${ }^{11}$ In Rennes, in 2015, 342 asylum seekers attended consultations in the medical center of the Louis Guilloux network, including over half from subSaharan Africa (DR Congo, Sudan, Somalia).

The study is based on a qualitative approach. It consists in interviews (56) with salaried professional interpreters for MSA and RLG (39), prominent members of these groups engaged in promoting the professionalization of interpreting (4), and mental health professionals (13). The professional interpreters interviewed work in Arabic, Berber, Russian, Georgian, Armenian, Italian, Bosnian, Albanian, Turkish, Kurdish and English. At the time of the interviews, their experience of the job could be very recent (a few months) or much longer, from a few years to over fifteen years.

The mental health professionals interviewed work (or have worked) as psychologists and psychiatrists (doctors and nurses) in hospitals, community health and mental health care centers (CMP), mobile mental health outreach teams (EMPP) or non-profit intersectoral care facilities. Those who agreed to meet us have varying degrees of experience with interpreters, and tend to defend the importance of interpreting in mental health care.

We were however unable to conduct first-hand observations during medical consultations; the health care professionals we asked refused on the grounds of doctor-patient confidentiality. Instead, we conducted observations of training sessions for interpreters and caregivers, which we provided upon requests of nonprofit groups.

\section{Interpreting in the medical and social field and the stakes of professionalization}

To discuss the stakes raised by the social, moral and spatial division of labor introduced or intensified by interpreting in health care for migrants requires summarily presenting the two associations that salary the interpreters we met. We will also examine the sociological backgrounds of these interpreters, to shed light on the intentions of professionalization connected to their practices.

The Rennes-based Louis Guilloux network (RLG) is a non-profit organization that is mainly funded by the regional health agency of Brittany. It includes a 'migrant' department (which comprises a health center named Louis Guilloux medical center) and an 'interpreting' department, and coordinates the DATASAM project (Technical support package on access to care for migrants), which aims at regionalizing access to health care for a 'precarious migrant public'. The interpreting department was established in the mid 2000s at the same time as the mobile mental health outreach team (EMPP). ${ }^{12}$ It began to be consolidated in 2010, especially thanks to national-level 
partnerships with non-profit groups working proactively for the recognition of the profession of interpreter in the medical and social field. Mainly in Rennes and occasionally elsewhere in Brittany, it offers in-person interpreting (the interpreter being physically present at the appointment) and phone interpreting services upon request. In 2015, the interpreting department comprised 19 interpreters working in 22 languages, for a total amount of 9,436 hours of work logged for the year (Rapport d'activités RLG, 2016: 27).

Created in 1975 under the name of Medico-Social Group of Assistance to Migrants, ${ }^{13}$ MSA (Migrations Health Alsace) is a non-profit group working to promote access to rights and health care for migrant populations. Interpreting is its main activity, and it has a large interpreting department, which in 2016 comprised 85 interpreters working in 38 languages, for a total amount of 26,023 hours of work logged for the year in both parts of Alsace (Bas-Rhin and Haut-Rhin) ${ }^{14}$ (Rapport d'activités MSA, 2016: 18).

Interpreting services in the mental health sector constitute a significant part of MSA and RLG's activities. Among the interventions made by MSA interpreters in hospitals, psychiatry is by far the biggest consumer of interpretation (for the year 2016, 6372.5 hours of intervention were logged). Interventions at the EPSAN (North Alsace Public Health Care Facility, a key structure for mental health) amounted for 24 percent of interpreting jobs in hospitals (Rapport d'activités MSA, 2016: 21-22). For RLG, psychiatry ranks third in terms of expenses, after the medical field (the activities of the Louis Guilloux medical center) and the social field (work with reception centers for asylum seekers). Interventions on behalf of the CHGR (hospital center specializing in psychiatry) are divided between the hospital, the CMPs and the EMPP.

\section{A highly ethnicized profession}

Interpreters hired by MSA and RLG have largely similar profiles. First, interpreting in the medical and social field is a highly feminized profession, as professions in the social sector generally tend to be (Bessin, 2005): in 2015, MSA had 65 female interpreters and only 16 men. At RLG, 14 out of 19 interpreters are women. Also, in the two organizations in question, the vast majority of interpreters are not French-born and have an experience of migration (for education or family-related reasons) or asylum some were granted refugee status; some were denied the status and subsequently legalized. Several of them have experienced or are experiencing a precarious situation in terms of residential status, which means they have a social proximity with the 'allophone' users of their services, who themselves are often faced with administrative uncertainty.

Interpreting careers very often begin through networks and word-of-mouth. For some, this is their first job, secured during or upon completion of their studies. Others have had previous professional experiences in fields such as teaching, commerce, health and social work. Jobs formerly held in France were often perceived as social downgrading in light of the individuals' levels of education or experiences in their countries of origin: 'I had everything working against me; age, origin. Nobody wanted me. Here, my origin is an asset. To tell you the truth, interpreting wasn't a choice initially', says an interpreter with five years of higher education who started doing this work when she was around 50 years old. While interpreting remains precarious work, ${ }^{15}$ (actual or supposed) origin is often 
perceived by the interpreters as a potential resource more than as a factor of discrimination.

As the vast majority lack degrees in the field of interpretation and/or translation, ${ }^{16}$ the know-how of these interpreters tends to have biographical sources. They generally work in their native language, and many of them have assisted relatives and friends in administrative procedures and health care appointments as interpreters - sometimes since a very young age. Others, as well as sometimes the same individuals, have experience as unpaid interpreters in non-profit groups specialized in aid to foreigners. The organizations that hire and pay interpreters have gradually launched a process of professionalization of the job.

The term professionalization refers to the processes 'of recognition and autonomy of categories of workers and their stabilization and legitimation as professional groups' (Demazière, 2009: 85). While the conditions of the emergence and use of the word professionalization elicited heated social debates in some professions (Wittorski, 2008: 9), in the case of interpreters, many of the stakes in the process were similar to other activities. This was about the intention of a group of individuals with the same activity to organize on the market, as well as the intention of institutions, organizations and non-profits to monitor the flexibility of labor. These processes often characterized by conflict or at least competition - also involve a normative and practical definition of the job's boundaries. On several levels, this dynamic triggered an effort at codifying what the interpreter's job should be and how it should be practiced. These initiatives can be seen as reflections of a process aimed at appropriating a 'mandate', in the sense of a recognized mission (Hughes, 1958), both to highlight the activity's value and to distinguish it from potential competitors (unpaid interpreters, family members, freelancers).

17 In 2012, in Strasbourg, a national working group bringing together 8 non-profits (including MSA and RLG) adopted a Charter for professional medical and social interpreting in France. ${ }^{17}$ This innovative charter set standards pertaining to ethics, the interpreters' responsibilities and the boundaries of their practice. In 2016, following a new health act that promoted language interpretation, these organizations were asked by the French national authority for health (HAS) to help in setting up professional standards and good practice guides for interpreting. This collective advocacy initiative launched in the mid 2000s ultimately led to the recognition of their legitimacy to formulate proposals in that area by national bodies. In what ultimately turned out to be a bottom-up process, they drafted the entirety of the document on professional standards, which is likely to be approved by the Ministry (Arend et al., 2017).

18 Now that interpreting has been granted legal recognition, talks are still underway regarding the boundaries of the interpreters' competencies in their collaboration with health care professionals. Internally, the organizations that promote professional interpretation are still working to codify the profession - an effort made particularly pressing by the fact that interpreters are led to work in multiple different structures (reception centers for asylum seekers, hospitals, mental health centers, etc.), with diverse partners and sometimes divergent expectations. These organizations' efforts to manage the social and moral division of labor between the actors translate in the creation of groups for analyzing practices, the introduction of mentoring systems and the strengthening of lifelong training. However, these interpreting resources, 
constructed and mobilized thanks to national partnerships, are locally put to work in different ways.

\section{The territorialization of health care: organizational differences between Rennes and Strasbourg}

19 Mental health facilities and professionals do not all operationalize the interpreting resources available locally in the same ways. They have to deal with local stakeholders (often connected with the medical and social sectors) and their progress depends on debates and negotiations between these stakeholders. Also, they find themselves implementing new practices regarding interpretation in a public health field characterized by territorialization, meaning a division between psychiatric sectors, which does not match other territorial divisions.

\section{The impact of the sectorization of psychiatric services on interpreting}

In France, the organization of psychiatry and mental health services has been marked by a twofold territorialization process. ${ }^{18}$ First, the sectorization of psychiatric services (inherited from the 1960 reforms and reviewed in 2009) defines its missions and organization. ${ }^{19}$ Second, it falls within the zoning programs implemented by regional health agencies. The co-existence of these two forms of territorial and institutional boundaries makes the coordination of health care highly complex. The psychiatric sector used to be characterized by a specific form of territorialization (inherited from its 'exclusive' functioning), but that is gradually giving way to crossings with health and social policy territories. From a niche (territorial and professional) position, mental health professionals have been transiting toward compliance with the orientations of the regional health agencies, intensifying their partnerships with the medical and social sectors (Rhenter and Rhenter, 2012). The 'philosophy of sectorization' (Ibid.) requires them to deal with these other professional ethics within the framework of multi-level regulation. ${ }^{20}$

The local level is where the mental health sector has changed the most in France. The territorialization of health and mental health public policies increasingly happens at micro levels: ideas such as 'proximity', 'consultation' and 'partnership' increasingly steer psychiatrists and psychologists toward organizing into bridged 'committees', 'teams', or 'networks' conducive to the introduction of new organizational forms (mobile mental health outreach teams [EMPP], local mental health councils [CLSM], mutual aid groups [GEM], forming local networks). These local bridged networks depend on rationales that are specific to each site, and are heterogeneous within the country and regional territories: as Coldefy and Le Neindre (2014: 51) point out, they 'should be related, first, with traditions in terms of welcoming immigrants (...) and second, with the policies being implemented and the initiatives of local actors'. We observed this in our fieldwork, where EMPPs and CMPs are on the front line of mental health care for migrants, supported by two professional interpretation structures in the field of health. 


\section{Interpreting and the distribution of mental health care facilities in Rennes}

In Rennes, the EMPP was created in 2002 after 'new mental health challenges pertaining to suffering and precariousness' were observed in the field, in the words of the psychiatrist and the psychologists during a late 2016 group meeting. The EMPP was then conceived as a 'new tool' allowing them to 'take a step toward' individuals in precarious conditions (Hoyez, 2015), and subsequently steer them to regular facilities. The team in Rennes quickly had to deal with migrants, a population requiring a distinct kind of work in some respects: for locals, according to team members, precariousness begins in childhood, whereas for migrants, the crux of the problem is often their administrative status, leading to residential precariousness and difficulties in accessing the health system.

Rennes has a very distinct local history of territorialization of psychiatric sectors. The EMPP's scope of action includes 47 municipalities (around 500,000 residents). When the EMPP receives a patient, in addition to providing primary care, they must direct him or her to a CMP located in one of the twelve sectors of their territory, which covers Rennes, Fougères, Vitré and Redon. Like everywhere else in France, the individuals who have a place of residence are directed to the CMP of their sector of residence. Homeless individuals are distributed into different CMPs depending on their month of birth. Persons born in January (01) are in sector G1; persons born in March (03) are in G3; persons born in May (05) are in G5 and so on. This system was inherited from the debates that followed territorial reforms in Ille-et-Vilaine, summed up by the EMPP's psychiatrist as follows:

"Everything was redrawn about ten years ago, with just three territories in Rennes and rural territories. Except they didn't change that business with the dates of birth, and so things are completely at a dead end vis-à-vis precariousness. And then nobody wants to change the system because that would mean that all the CMPs in Rennes would accept to see all the homeless people in Rennes provided they get the others' resources... And the others don't want to let go of their resources. So it's a dead end. And nobody's chasing after those patients, anyway.y" (Interview, 2016)

This distribution - which raises both the question of the allocation of resources and of the type of public cared for - is considered imperfect by many of the caregivers we met. It is even accused of leading to incongruous situations, as the same psychiatrist explains:

"A migrant requiring treatment for PTSD, here in Rennes, if he were born in March, he should in theory go to Fougères. But the thing is, in practice, we can do patient follow-up here in the psychiatric hospital, in the psychiatrist's office. But it's not multidisciplinary care like in the CMP. It's just a psychiatrist doing the consultations. There's no psychologist. No nursing care. Mainly, it's just giving out anti-depressants every two months, renewing prescriptions of psychotropic drug.s" (Interview, 2016)

Due to this distribution system, the EMPP also struggles to refer patients to CMPs outside of Rennes, and ends up dealing with four times the number of patients that the CMPs see. Likewise, the Rennes-based CMPs see more patients than the other CMPs in the territory, due to their geographical proximity with the homeless, precarious population, which includes migrants. As the migrants account for half of the EMPP's activity, the team was very quickly contacted by the Louis Guilloux network when it 
was created. These two structures with converging interests have established a longterm coordination since 2006, especially regarding professional interpretation.

\section{Interpreting and the organization of psychiatric care in Strasbourg} rejected asylum seekers or illegals. Caregivers tend to distinguish between non-foreign addictions) and foreigners with disorders connected to migration and exile, with or without co-occurring disorders. Depending on the successive coordinating physicians since the PASS opened in the mid 2000s, the 'migrant public' has received varying degrees of attention. Once patients have become officially entitled to health care, with the help of the PASS's social services, they continue to be treated by the same EMPP team if they are or claim to be homeless. Indeed, out of fear of public authorities, some undocumented migrants choose not to give their home address (even if they do have one) to caregivers. Those who do indicate an address are liable to be referred to the CMP in their residential sector. It also frequently happens that when they become officially eligible to health care, migrants indicate an address that is not considered stable by the teams - particularly when they are accommodated in emergency housing structures, in reception centers for asylum seekers or by support groups for immigrants. If they have children in kindergarten or primary school, referral to the sectoral CMP is based on the school's address. If they do not, the patients continue to receive treatment at the Berne CMP. However, referrals may be subject to internal arrangements, in order to make sure that the workload is more evenly distributed across the Eurometropolis and to avoid clogged waiting lists. These choices also depend on the urgency of the situation, on the type of disorder and on the patients' social bonds. What is at stake is to ensure the continuity of care ${ }^{21}$ system on a long-term basis, meaning referring them to public hospitals, sectoral psychiatric care facilities or private psychiatry practices - the latter forming an interconnecting network of care, between whose points patients may move during the course of their trajectory. Hospitalized migrants are referred based on the initial of their surname to one of three psychiatric facilities in the Bas-Rhin (EPSAN in Brumath, department of psychiatry at the Hôpital Civil in Strasbourg, department of psychiatry at the Erstein hospital center). The Berne CMP and the EMPP have had a notably frequent recourse to professional interpreters from MSA for a few years. ${ }^{22}$ As they are identified as structures with interpreting resources, private physicians and non-profits will sometimes refer patients to them that do not always require psychiatric care or are not in the right sector. These patients are in turn redirected by the CMP and the EMPP.

In Strasbourg, in addition to these public hospital structures, the non-profit organization Words Without Borders (Parole Sans Frontière - PSF) is a front-line actor of mental health care for the so-called allophone migrants. PSF was created in the early 1990s by psychologists and psychiatrists eager to provide psychotherapeutic care to non-Francophone migrant populations. It offers training seminars for psychiatry 
residents, and free consultations with interpreters for patients from all over the BasRhin area. The team currently comprises four part-time (salaried or temp) psychologists ${ }^{23}$ and a volunteer psychiatrist, who also has her own practice. PSF receives support from the regional health agency, the municipality of Strasbourg and the United Nations to offer psychotherapeutic care that complements the CMP and the EMPP's in several respects. First, PSF has developed a program for migrants who have been victims of torture and trauma relating to their migratory conditions and/or spousal violence. PSF's activity is also designed to prevent migrants with precariousness-related disorders from going without treatment because they are not eligible to public health care. The organization also receives patients that were first referred to the EMPP, but relocated and were subsequently redirected to a sectoral CMP, which may be far from the city center or even far from Strasbourg. Those who prefer to receive care in the city center thus turn to PSF, whose activities do not fall within the sectorization system.

29 Migrants are referred to PSF through several channels. Word-of-mouth between compatriots is an important one, but others are also referred by partner networks, such as aid organizations for asylum seekers and undocumented immigrants. These referrals may be motivated by territorial concerns, an effort to bypass sectorization and in some cases avoid a breakdown in the continuity of care following a relocation. They can also be owed to PSF's specific therapeutic program for migrants who have suffered torture and violence. Here, networks ${ }^{24}$ are central, both for referrals and for ensuring that a comprehensive approach to health care is pursued. Between 2014 and 2015, PSF actually had reserved consultation slots for unaccompanied minors, many of whom lived in a hotel for lack of space in shelters. Failing adequate socio-educational monitoring, PSF decided to discontinue these consultations on the grounds that effective psychotherapeutic care was impossible under such conditions. By defining a broader scale of action than psychiatric sectorization, PSF has contributed to constructing new health care spaces, although its activities may be limited by the requirements of comprehensive care. Also, PSF is unable to follow patients whose disorders require institutional mental health care.

30 Our focus on interpreting in mental health in Rennes and Strasbourg helps evidencing the heterogeneity of health care for migrants in France. This heterogeneity (Hoyez, 2011; D'Halluin and Hoyez, 2012), which is due to the challenge of streamlining health care circuits in the presence of so many non-medical issues (asylum or immigration status, housing, social isolation, etc.), is heightened by inequalities in the interpretation offer between territories. Also, the existence of proactive initiatives on interpreting on a given territory does not mean that all professionals in that area will readily use an interpreter's services to work with these populations.

\section{Reluctance in the professional landscape}

31 The reluctance of some health care professionals to provide care to migrants may relate either to that specific type of patients or to the interpreting aspect.

First, the time-consuming aspect of setting up a consultation with an interpreter can led some to turn down these patients: a form needs to be filled out for the structure providing the interpreter; interpreter and patient must both be available at the same time, these consultations are longer than regular ones, etc. A further organizational 
constraint lies in the efforts to rationalize the costs of interpreting, which entails attempting to try and schedule several appointments with different patients and the same interpreter over the course of half a day.

Political considerations also come into play. The risk of an unbalance in the pool of patients is sometimes brought up - there are fears that if the proportion of migrants is too high, then the universality of the health care system and the public service mission for all citizens will be threatened. Some professionals also fear disqualification arising from an unwanted posterity effect that might ripple over to them due to the stigma weighing on their foreign patients. The psychotherapeutic follow-up of precarious migrants is also sometimes described as ineffective and undermined by administrative uncertainty, when they are undocumented or awaiting a decision as to their asylum status. A psychiatric nurse practicing in an EMPP thus points to the 'issues' pointed out by colleagues regarding that aspect:

"When you're working with PTSD, some people will want the person to be legal so that there is no interference in their everyday situation, especially with all things related to housing and money. That is a fact: people who are preoccupied in their daily lives will not necessarily be able to work on their PTSD." (Interview, 2016)

In his view, the condition of legal residency and/or stable housing required by some colleagues constitutes an insidious form of denial of treatment. The question of the instrumentalization of care, or even of the misuse of care for administrative reasons, has also elicited debates. Stereotypical representations of the economic migrant, here to game the system, which also occur in other health care settings (Pian, 2012; 2016), may factor in the reluctance of some to deal with these patients. These representations reflect the complex intertwining of immigration and public health policies, which has been documented since the 1990s (Fassin, 1999; Fassin and D'Halluin, 2005; Musso, 2012).

35 Also, according to some psychologists and psychiatrists, this population requires specific care due to the traumatic events they have experienced in their country of origin or on the roads of migration, which they find themselves unable to provide. Others feel insufficiently prepared to deal with exceedingly 'anxiety-inducing' situations, which they argue would require extra work 'on the side' for the therapist. Political and therapeutic arguments mix, tied in with concerns about working with interpreters or an outright refusal to do so. This reluctance involves 'dogmatic' considerations (in the words of a psychologist) pertaining to the introduction of a third party in the patientdoctor relationship: 'Working with three people that way, it's not part of the culture in psychiatry', a nurse practicing in an EMPP notes. Practical concerns are also voiced by some who do not 'know how to work with an interpreter' - a presence that effectively changes the dynamic of the interactions.

Conversely, practitioners who are highly invested in care for the migrant populations tend to have followed similar professional and biographical trajectories. They have experience of living abroad or personal or familial experience of migration to France. They have been trained in ethnopsychiatry or transcultural psychiatry, although they may have become subsequently critical of these approaches, during their medical studies or over the course of professional experiences abroad (in places such as the Antilles, Africa or Romania), and they present this experience as fundamental to their interest in alterity in their professional practice. Lastly, they tend to be sympathetic to the migrants' plight, ${ }^{25}$ and have sometimes been migrants' rights activists, as 
exemplified by the 2017 book Migrants, le cri de Strasbourg, on hospitality for refugees in Europe.

The health care landscapes described here remained characterized by reluctances and challenges for caregivers. This influences orientations and referrals, as the structures and the professionals who agree to work with interpreters are quickly identified with that role and assigned to it. The following section investigates the perspectives of the interpreters themselves.

\section{The challenges of consultations with interpreters}

Depending on the interpreter, the challenges of interpreting in mental health may not be limited to the emotional dimension of the job - of which some psychologists and psychiatrists are particularly aware, leaving some time at the end of their consultations for a short debriefing. These challenges tend to reside more broadly in the demands of this kind of work.

\section{Debates around word-for-word translation}

When interpreters compare their work in the mental health field with other fields, they frequently point out the specific demands that comes with this particular territory. One notes that 'for shrinks, every single word matters':

"I've had a psychologist ask me: did he say that word? The thing is, you don't translate a word on its own, you have to translate it in context, and sometimes with the context I'm forced to change words, to use other words that haven't actually been spoken. So that's difficult in psychiatry. Do you have to be faithful to the meaning or the word? If you can do both, great, otherwise [...] ... Attaching meaning to the word, sure, you can do that, but not too much. That's why interpreting is very difficult in psychiatry." (Female Russian language interpreter, 2015)

Several interpreters also point to the difficulty of translating often disjointed discourses, which requires performing particularly exhausting 'linguistic gymnastics' (Sinha, 2011): ${ }^{26}$ an interpreter with around ten years in the field told us humorously that interpreting in these conditions requires 'being a psychologist yourself, as well as a sorcerer's apprentice'. Translating disjointed discourses poses a double challenge. When the interpreter attempts to remain as faithful as possible to the patient's words, this can cause misunderstandings as to the quality of their services and skills, whenever the caregiver struggles to decipher the message:

"There are professionals who will stare at you, like an owl sometimes, while you're translating. They just stare and measure the time and the number of words spoken [...] The psychiatrists tend to do that, and the psychologists are even worse. I don't know why those [...] categories of professionals pay such close attention. Maybe they don't trust our ability to translate everything in good French, structured like theirs. Or because the language of psychologists and psychiatrists is so complex. [...]." (Male Arabic language interpreter, 2016)

Yet, a number of psychologists or psychiatrists with experience of working with interpreters played down this idea that they are extremely demanding regarding wordfor-word accuracy.

"I've seen interpreters find themselves dealing with a delusional person. The interpreter was very confused because their discourse was incoherent, and what he conveyed [was as well]. At one point, he told me: "I'm just translating what I'm hearing. I said: "Yes, that's what I'm 
asking you to do", you have to tell them, because even though what they're hearing doesn't seem coherent to them, they need to translate it because that's what will allow us to see [what disorders are being exhibited]." (Nurse practicing in an EMPP, December 2016) appropriate their role in their own ways. The professionals we encountered did however emphasize the need for interpreting without reconstruction or transmission of gestures and emotions that would 'interfere' with their work. To one psychologist, interpreting requires accepting to work with the signifier (the translated word) rather than the signified (the 'turns of phrase that identify a psychopathology'). The same psychologist stresses the need to be able to distinguish what comes from the 'interpreter's psyche at work', as she points out that they are 'always necessarily interpreting something'. This is particularly the case when the patient's history echoes their own subjectivity. Thus, while for some psychiatrists, an interpreter who 'manages to forget herself' and 'use the first person' is best, this way of translating is not necessarily imposed. In her research, Wang (2016) shows the back and forth between first and third person to be a source of uneasiness in interpreters, who are seeking to convey the patient's speech without turning themselves into mediators. This uncertainty in the interactions can lead them to 'mix up the recipients of the psychiatrists' questions' (Ibid: 143) or at least force them to grapple with many doubts.

For the caregivers we encountered, building a three-way relationship of trust is essential to the therapeutic dynamic. Some argue that it is important to work with the same interpreter throughout the patient's treatment, as that person is part of a "continuum developed together from consultation to consultation". Yet excessive proximity is depicted as causing unwanted effects: one risk is that the patient will become passive in the interactions, and leave things up to the interpreter. Another potential issue is that interpreters can be led to act as advocates by formulating requests on the patient's behalf at the beginning or the end of a consultation, a practice that does not always go over well with caregivers.

While the caregivers' demands on interpreters, such as they were conveyed to us, may vary, some practices are simply never tolerated. This applies for instance to an interpreter directly asking the patient for additional information or clarification without going through the therapist first. Any interpreter doing this will be reprimanded for failing to comply with the social and moral division of labor, which involves hierarchy and power relations (Leanza, Boivin, Rosenberg, 2010) within the space of the consultation. This division of labor may be likewise challenged by the cultural explanations ${ }^{27}$ of interpreters.

\section{"We're not [only] translation robots"}

Psychiatrists perceive interpreters as potential 'code breakers' allowing them to better contextualize the patients' discourse - they can for instance ask for their opinion as to the patient's rural or urban background based on the kind of language they use, or ask for more information on the organization of schooling in the country of origin or the specificity of a given educational institution. According to some of the caregivers we met, showing interest in the patient's culture may also lead the patient to open up by giving them 'a stronger narcissistic footing' (interview, psychologist, 2016). These cultural contributions will also in some cases ensure that the caregiver will not consider the 
patient's discourse as delusional when they are in fact referring to customs and traditions from the country of origin.

In practice, the interpreter is sometimes the one who initiates such contributions, especially when they are used with working with that therapist and aware that they are open to such interventions. A Russian language interpreter recounted the following scene:

"I had a psychological consultation where the lady was saying that in her first marriage, she'd been whisked off by her husband, who she didn't even know, she'd seen him once, her husband $[. ..] ._{.8}^{28}$ So, I translate that and the psychologist looked lost, because imagine being told in France right now, you know: "You've never known the person and then you go out, you get whisked off, and you're forced to stay with that person for the rest of your life, have children and family" [...] So I told myself I had to clear things up for him. He looked at me because he didn't understand anymore. Was the lady delusional or was this really... So, I told myself that this was a tradition that did exist in Georgia, and maybe is rarer now, but twenty years ago this was still a common thing [...] I'm not going to play a role where the psychologist thinks the patient is delusional and making things up when I know this stuff really happens in the country."

In this case, based on her 'definition of the situation' (Thomas, 1928), the interpreter anticipated the psychologist's demand and need for cultural explanations regarding a practice occurring in the patient's country of origin, which is also the interpreter's. She justifies her initiative (subject to the psychologist's approval, and she asked him beforehand whether he would be interested in a cultural explanation) on the grounds that it would avoid misunderstandings in the health care relationship, which she would have blamed herself for.

In their research on interpreting in mental health, Chambon and Carbonel (2015) noted that interpreters are 'autonomous in spite of [themselves]', due to the flexibility and sometimes unclear definition of their roles in practice. Furthermore, they often find themselves dealing with contradictory demands - those of the professionals who use their services, and the prescriptions of their employers, who may see taking on a role of 'cultural mediator' as overstepping the job's boundaries. According to MSA, for instance, ${ }^{29}$ interpreters must refrain from engaging in mediation and adopt a posture of distance from the patient's emotional environment. Without acting as experts in the culture of foreign patients, they are expected to practice inter-cultural attention so as to avoid possible misunderstandings. Yet, in actual interactions, the line between cultural mediation and intercultural attention can be crossed very quickly.

Lastly, it should be noted that the mental health professionals we met adopted different stances toward these cultural contributions. Some are rather open to them, but particularly careful as to how they take them into account in the therapeutic process. Others are very reluctant on principle, on the grounds that this is necessarily situated knowledge and that the interpreters sometimes migrated a long time ago, and have become removed from the culture of their country of origin. Some interpreters also voiced similar reservations, but others depicted their contributions as a source of value: 'we're not translation robots', as one of them put it. Not being a robot, in their view, means being mindful of misunderstandings, humanizing the relationship, making the necessary adjustments and in some cases claiming expertise. 


\section{Conclusion}

In the process of studying interpreting in mental health in terms of social, moral and spatial division of labor, this paper has combined two perspectives - on actors and on territories - and as a result documents two angles to the same subject: one focusing on socio-territorial inequalities in health care in light of migratory issues; the other emphasizing the negotiations at play at the heart of the therapeutic dynamic in that context. This multidisciplinary approach situates the ways in which mental health care professionals and interpreters envision their respective practices and places, and documents the structure of the local health care landscape. Concurrently, our attention to the socio-spatial dimension is conducive to a better understanding of how professional practices and organizations develop and distinguish themselves: the different approaches evidenced in our fieldwork are based on social and territorial rationales that relate as much to the dynamic of professional relations as to the forms of access for migrants at local level.

51 More broadly, we argue that the issue of interpreting in mental health might actually hold a mirror to the greater issue of health care for migrants. Like school staff and social workers, caregivers are to some extent caught up in the apparent neutrality of the new 'allophone' institutional category, which relates to contemporary immigration and asylum policies. ${ }^{30}$ In that sense, our examination of interpreting in mental health has both therapeutic and political implications.

Three aspects of our study deserve further scrutiny. First, it might be interesting to conduct more in-depth studies in the field of mental health to assess whether interpreting poses different challenges in psychiatric, nursing and psychological care, as well as for the social workers who practice in EMPPs and CMPs. Then, instead of only taking into account the international migrations of interpreters, a change of scale to zoom into their everyday mobilities would be worthwhile - so as to also relate their professionalization with the urban and extra-urban forms of mobility that are specific to their job. Lastly, another possible extension of this research would consist in broadening the multidisciplinary approach introduced here adding a diachronic level to our analysis. Drawing on archival research on patients' records, this would consist in assessing the impact of the presence of interpreters over the long term.

\section{BIBLIOGRAPHY}

Arend Louise, Cadart Aurélien, Chabagno Lucie, Delepoulle Ndiaye Anna, Deseille Reynald, Gautier Anne, Guiffault Tiphaine, Moutou Karine, Thomin Émilie et Urcun Mélisande (2017) L'interprétariat médical et social, élément de la démocratie sanitaire, Rapport, Module Inter Professionnel de Santé Publique, Rennes, École des Hautes Études en Santé Publique, 53 p. Armagnague-Roucher Maïtena, Cossée Claire, Mendonça Catherine, Rigoni Isabelle et Tersigni Simona (2018) Étude sur la scolarisation des élèves allophones nouvellement arrivés (EANA) et des enfants 
issus de familles itinérantes et de voyageurs (EFIV) (EVASCOL), Rapport de recherche, Défenseur des Droits, $418 \mathrm{p}$.

Armagnague-Roucher Maïtena et Tersigni Simona (2019 [à paraître]) L'émergence de l'allophonie comme construction d'une politique éducative: le traitement scolaire des enfants migrants en France, Émulations.

Beal Arnaud et Chambon Nicolas (2015) Le recours à l'interprète en santé mentale: enjeux et problèmes, Cahiers du Rhizome, 55, pp. 9-19.

Bessin Marc (2005) Le travail social est-il féminin ?, in Jacques Ion Éd., Le travail social en débat(s), Paris, La Découverte, pp. 152-169.

Bonny Yves, Bautès Nicolas et Gouëset Vincent (Dirs.) (2017) L'espace en partage. Approche interdisciplinaire de la dimension spatiale des rapports sociaux, Rennes, Presses Universitaires de Rennes, $360 \mathrm{p}$.

Bourdin Marie-Jo et Larchanché Stéphanie (2015) De l'interprétariat à la médiation en santé mentale: l'expérience du centre Françoise Minkowska, Les Cahiers du Rhizome, 55, pp. 48-54.

Chambon Nicolas et Carbonel Natacha (2015) L'interprète, un intervenant en santé mentale, Les Cahiers du Rhizome, 55, pp. 86-97.

Chambon Nicolas et Le Goff Gwen (2016) Enjeux et controverses de la prise en charge des migrants précaires en psychiatrie, Revue française des affaires sociales, 2, pp. 123-40.

Cognet Marguerite, Hamel Christelle, Sauvegrain Priscille et Gabarro Céline (2014) Migration et état de santé, in Jean-Yves Blum-Le Coat et Mireille Eberhard Éds., Les immigrés en France, Paris, La documentation française, pp. 133-146.

Coldefy Magali (2016) Les soins en psychiatrie: organisation et évolutions législatives récentes, Revue française des affaires sociales, 6, pp. 21-30.

Coldefy Magali et Le Neindre Charlène (2014) Les disparités territoriales d'offre et d'organisation des soins en psychiatrie en France: d'une vision segmentée à une approche systémique, Les rapports de l'IRDES, 558, [en ligne]. URL: http://www.irdes.fr/recherche/rapports/558-lesdisparites-territoriales-d-offre-et-d-organisation-des-soins-en-psychiatrie-en-france.pdf Crenn Chantal et Kotobi Laurence (2012) Du point de vue de l'ethnicité, pratiques françaises, Paris, Armand Colin, 348 p.

Cuche Denys (1996) La notion de culture dans les sciences sociales, Paris, La Découverte, $128 \mathrm{p}$.

Demazière Didier (2009) Postface: professionnalisations problématiques et problématiques de la professionnalisation, Formation emploi, 108, pp. 83-90.

De Rudder Véronique, Poiret Christian et Vourc'h François (2000) L'inégalité raciste. L'inégalité républicaine à l'épreuve, Paris, PUF, $224 \mathrm{p}$.

D’Halluin Estelle et Hoyez Anne-Cécile (2012) L'initiative associative et les reconfigurations locales des dispositifs d'accès aux soins pour les migrants primo-arrivants. Humanitaire, 33, [en ligne]. URL: http://humanitaire.revues.org/1407

Eliot Emmanuel, Lucas-Gabrielli Véronique et Mangeney Catherine (2017) Territorialisation sanitaire et décentralisation: état des lieux et enjeux à partir du cas français, Revue francophone sur la santé et les territoires, [en ligne] consulté le 10/07/2017. URL: https://rfst.hypotheses.org/ eliot-emmanuel-lucas-gabrielli-veronique-mangeney-catherine Fassin Didier (Éd.) (2012) Les nouvelles frontières de la société française, Paris, La Découverte, 590 p. 
Fassin Didier (2000a) Les politiques de l'ethnopsychiatrie, L'Homme, 153, [en ligne] consulté le 25/05/2018. URL: http://journals.openedition.org/lhomme/14

Fassin Didier (2000b) Repenser les enjeux de santé autour de l'immigration, Hommes et Migrations, 1225 , pp. 5-12.

Fassin Didier (1999) Santé et immigration. Les vérités politiques du corps, Cahiers de l'Urmis, 5, [en ligne] consulté le 30/08/2018. URL: http://journals.openedition.org/urmis/351

Fassin Didier and D'Halluin Estelle (2005) The Truth in the Body. Medical certificates as ultimate evidence for asylum-seekers, American Anthropologist, 107 (4), pp. 597-608.

Hachimi Alaoui Myriam et Nacu Alexandra (2010) Soigner les étrangers en situation irrégulière. Des politiques migratoires aux postures professionnelles, Hommes et Migrations, 1284, pp. 163-173. Hassenteufel Patrick (2008) Syndicalisme et médecine libérale: le poids de l'histoire, Les Tribunes de la santé, 18 (1), pp. 21-28, [en ligne]. URL: https://www.cairn.info/revue-les-tribunes-de-lasante-2008-1-page-21.htm?contenu=article

Hoyez Anne-Cécile (2015) Territoires, mobilités et santé: comment composer et penser une offre de soins pour les populations migrantes en situation précaire ?, Revue Francophone sur la Santé et les Territoires, [en ligne]. URL: https://rfst.hypotheses.org/hoyez-anne-cecile-territoiresmobilites-et-sante-comment-composer-et-penser-une-offre-de-soins-pour-les-populationsmigrantes-en-situation-precaire

Hoyez Anne-Cécile (2011) L'accès aux soins des migrants en France et la « culture de l'initiative locale ». Une analyse des contextes locaux à l'épreuve des orientations nationales, Cybergeo, [en ligne]. URL: http://cybergeo.revues.org/24796

Hughes Everett C. (1958) Men and their Work, Glencoe, The Free Press, 184 p.

Kessar Zahia (2000) La formation en anthropologie à l'hôpital, Hommes et Migrations, 1225, pp. 112-117.

Kotobi Laurence, Larchanché Stéphanie et Kessar Zahia (2013) Enjeux et logiques de recours à l'interprétariat en milieu hospitalier: une recherche-action autour de l'annonce d'une maladie grave, Migrations santé, 146-147, pp. 53-80.

Laval Christian et Zeroug-Vial Halima (2015) L'interprétariat en santé mentale, Cahiers $d u$ Rhizome, 55, 101 p., [en ligne] consulté le 31/01/2017. URL: http://www.ch-le-vinatier.fr/orsperesamdarra/rhizome/anciens-numeros/cahiers-de-rhizome-n55-l-interpretariat-en-santementale-1058.html

Leanza Yvan, Boivin Isabelle and Rosenberg Ellen (2010) Interruptions and resistance: a comparison of medical consultations with family and trained interpreters, Social Science and Medicine, 70 (12), pp. 1888-1895.

Le Défenseur des droits (2016) Les droits fondamentaux des étrangers en France, Paris, 305 p.

L'information psychiatrique (2015a) Migrants (1/3), L'information psychiatrique, 91 (1), pp. 9-65, [en ligne]. URL: https://www.cairn.info/revue-l-information-psychiatrique-2015-1.htm

L'information psychiatrique (2015b) Migrants (2/3), L'information psychiatrique, 91 (2), pp. 97-144., [en ligne]. URL: https://www.cairn.info/revue-l-information-psychiatrique-2015-2.htm

L'information psychiatrique (2015c) Migrants (3/3), L'information psychiatrique, 91 (3), pp. 203-254, [en ligne]. URL: https://www.cairn.info/revue-l-information-psychiatrique-2015-3.htm

Musso Sandrine (2012) Être régularisé au titre de la maladie en France, Corps, 10 (1), pp. 153-161. 
OFII (2017) Rapport d'activité 2016, Office français de l'immigration et de l'intégration, 101 p.

ORIV (2017) Note Statistique de l'Observatoire Régional de l'Intégration et de la Ville (Immigrés-es et primo-arrivants-es dans le Grand Est), $6 \mathrm{p}$.

Payet Jean-Paul (1997) Le « sale boulot ». Division morale du travail dans un collège en banlieue, Les Annales de la recherche urbaine, 75, pp. 19-31.

Pestre Élise (2010) La vie psychique des réfugiés, Paris, Payot et Rivages, 377 p.

Pian Anaïk (2016) Tourisme médical versus immigration thérapeutique: des catégories exogènes réductrices, Revue francophone sur la santé et les territoires, [en ligne]. URL: https:// f.hypotheses.org/wp-content/blogs.dir/1946/files/2016/10/Pian_rfst_2016_TMS.pdf

Pian Anaïk (2014) La fabrique de l'interprétariat auprès des immigrés atteints de cancer: la place des proches en question in Florence Douguet, Françoise Leborgne-Uguen et Simone Pennec Éds., Les négociations du soin. Les professionnels, les malades et leurs proches, Rennes, PUR, pp. 193-204.

Pian Anaïk (2012) De l'accès aux soins aux trajectoires du mourir. Les étrangers atteints de cancer face aux contraintes administratives, Revue Européenne des Migrations Internationales, 28 (2), pp. 101-127.

Piret Bertrand et Douville Olivier (Dirs.) (2017) Migrants, réfugiés, la politique interroge la clinique, Psychologie clinique, 43 (1), pp. 5-6.

Plateforme d'accueil des Demandeurs d'Asile (2016) Compte-rendu narratif-Année 2015 de la plateforme d'accueil des demandeurs d'asile de Rennes, $21 \mathrm{p}$.

Rechtman Richard (1992) L'intraduisible culturel en psychiatrie, L'évolution psychiatrique, 57 (3), pp. 347-365.

Rhenter Helène et Rhenter Pauline (2012) Les ambiguïtés de la nouvelle territorialisation, in Lise Demailly et Michel Autès Éds., La politique de santé mentale en France. Acteurs, instruments, controverses, Paris, Armand Colin, pp. 141-152.

Rhenter Pauline et Michel Jacques (2010) Culture et identité: la psychiatrie publique à l'épreuve, in Michel Joubert et Claude Louzoun Dirs., Répondre à la souffrance sociale, Paris, Érès, pp. 117-135. Simon Pierre-Jean (2006) Pour une sociologie des relations interethniques et des minorités, Rennes, Presses Universitaires de Rennes, $347 \mathrm{p}$.

Sinha Shumona (2011) Assommons les pauvres, Paris, L'Olivier, 149 p.

Tabouri Aziz (2009) L'interprétariat dans le domaine de la santé, Hommes \& Migrations, 1282 (6), pp. 102-107.

Thomas William Isaac and Swain Thomas Dorothy (1928) The Child in America. Behavior Problems and Programs, New York, Alfred Knopf, 553 p.

Veïsse Arnaud, Wolmark Laure, Revault Pascal, Giacopelli Maud, Bamberger Muriel et Zlatanova Zornitza (2017) Violence, vulnérabilité sociale et troubles psychiques chez les migrants/exiles, Bulletin Épidémiologique Hebdomadaire, 20-21, pp. 406-414.

Wang Simeng (2016) « Aidez-nous à comprendre vos Chinois ! . Conditions de possibilités de la légitimation du sociologue en milieu psychiatrique, Genèses, 4 (105), pp. 141-156.

Wittorski Richard (2008) La professionnalisation, Savoirs, 2 (17), pp. 9-36. 


\section{NOTES}

1. This article received support from the Maison Interuniversitaire des Sciences de l'Homme d'Alsace (MISHA) and the Excellence Initiative of the University of Strasbourg.

2. This category is in particular mobilized very explicitly in the education system. See Armagnague-Roucher et al., 2018 and Armagnague-Roucher and Tersigni, 2019.

3. Numerous social science studies have examined the effects of the national Republic 'tradition', which claims to be universalist but nevertheless produces ethnic and racial categories in institutions and in common sense representations (De Rudder et al., 2000; Simon, 2006; Fassin, 2012; Crenn and Kotobi, 2012).

4. Article 90 points out the need to 'improve access to rights, prevention and care for the people who are far from the prevention and health care systems, taking their specific needs into consideration'.

5. Article D. 1110-6 of this implementing decree reads: 'Language interpretation in the area of health refers to the function of interface, based on oral translation techniques, that is fulfilled between individuals who have little or no mastery of the French language and the professionals involved in their health care, so as to ensure that these individuals have the means of communication allowing them to have autonomous access to the rights provided for by this regulation, to prevention and to health care. Language interpretation in the area of health ensures that health care professionals have the means to care for individuals who have little or no mastery of the French language in accordance with their rights provided for by this regulation, including the right to information, the right to free and informed consent, the right to privacy and the right to confidentiality of information pertaining to them.'

6. Discourses and practices excluding foreign or foreign-trained physicians from the medical community have been part of this history (Hassenteufel, 2008). Also, for several decades, training in anthropology, ethnology, or in the 'study of cultures' or 'intercultural health care' has been offered as part of a movement that promotes humanized health care, aiming to turn the patient into an 'autonomous' and 'responsible' actor (Kessar, 2000). However, the author shows that the challenges encountered in health care are not so much due to a lack of knowledge of other cultures in hospitals, but more broadly to the configuration of health care, characterized especially by a 'lack of communication on the patient between professionals' (Ibid.).

7. This broad category is used in particular by professionals in the medical and social sector, and covers multiple statuses (asylum seeker, illegal, refugee, etc.). The patients called by that word have in common their labelling as vulnerable, precarious individuals.

8. While this may not be reflected in the gender-neutral terms employed here to refer to the individuals, gender relations play a role in consultations, both between patients and caregivers and with interpreters.

9. The study does not address consultations for children, but this would be valuable fieldwork.

10. Fieldwork was conducted as part of two research projects: PEPS MSH-IMSODA (2016-2017) and ANR MIGSAN (2016-2019).

11. Source: 2015 narrative report of the welcome platform for asylum seekers in Rennes (dated 2016).

12. The EMPP is attached to the Guillaume Régnier hospital center - a public mental health institution.

13. This name (Groupe Médico-social d'Aide aux Migrants) was changed in 1988 to Migrations Santé Alsace.

14. MSA also has an office in Mulhouse.

15. Many interpreters are employed under a CDII contract (intermittent open-ended contract), meaning they have a yearly allocation of adjustable hours. Many have another salaried job (various types of contract work, food industry work, home help, etc.). Despite their 
precariousness in terms of income, working part-time and being able to indicate periods of unavailability to the employers is sometimes perceived as an advantage, enabling them as it does to combine the job and family life, studies, etc. Several salaried interpreters also work concurrently as sworn interpreters and translators for courts and police stations.

16. At MSA and RLG, the majority of interpreters have three or four years of higher education. Requirements are lower when it is difficult to find an interpreter in a given language.

17. The other organizations are ADATE (Grenoble), APTIRA (Angers), ASAMLA (Nantes), COFRIMI (Toulouse), ISM (Lyon and Paris branches), and MANA (Bordeaux).

18. The term 'territorialization' takes into consideration both public policy and the governance and government processes that reshape systems of action at various local levels (Eliot, LucasGabrielli and Mangeney, 2017).

19. The concept of psychiatric 'sector' appeared in the 1960s during the trend towards the deinstitutionalization of psychiatric care. A sector is a territorial entity that is independent from the other administrative subdivisions, and in which public and private health care professionals commit to implementing a comprehensive coordination of health care (prevention, care, social rehabilitation). This involves a multidisciplinary effort to care for patients 'as close as possible to their living space' (Coldefy, 2016).

20. The January 2016 health act confirms the existence of sectorized psychiatry, but it also situates psychiatry within the overarching mental health policy, which does not only consist in psychiatric care (Coldefy, 2016).

21. Transfers to sectoral CMPs may however cause breakdowns in the continuity of care; some professionals see this as a regrettable effect of sectorization.

22. In the EMPP's lobby, which serves as a waiting room opposite the secretary's office, a poster in French states that interpreters are provided by MSA, and that the hourly costs of interpretation are paid for by the hospital. Patients are required to give 24-hour notice in case of cancellations. It is also mentioned that it is possible to request the same interpreter for different appointments, or to request a different interpreter if needed (for instance, when the patient has a preference for a male or female interpreter, etc.).

23. Some among them are also able to work in English, Turkish, German or Russian.

24. PSF also has close ties with the RESPIRE network, which brings together therapists with a interest in the use of interpreters in mental health.

25. They may also be engaged in favor of other so-called at-risk populations.

26. Additionally, there are also challenges related to purportedly 'untranslatable' terms.

27. We use the term 'culture' but do not partake in a culturalist approach, like studies on interethnic relations. See Cuche (1996) and Simon (2006).

28. Bride kidnapping, or marriage by abduction, is a practice that occurs in the Caucasus region, among others.

29. MSA produced a brochure on professional interpretation in 2015.

30. See Armagnague-Roucher et al. (2018) and Armagnague-Roucher and Tersigni (2019).

\section{ABSTRACTS}

Simultaneous interpreting in the context of mental health care for migrants faces several political issues, which result in questioning such professional practices towards patients whose 
mental suffering is often related to the experience of exile. Consultation sessions with migrants represent a challenge for interpreters as well. These professionals are required to position themselves in a caring relationship, while dealing with mental health professionals' expectations together with employers' directives, which may overlap and contradict each other. Through the prism of interpretation, the paper aims at examining the social, moral and spatial division of labour in migrants' care, namely in the context of mental health services. The presentation is based on two separate field-works, in the cities of Rennes and Strasbourg: both regional capitals are marked by recent significant changes in migration flows and have been considered for experimenting innovative practices in promoting simultaneous interpretation in the context of mental health care.

L'interprétariat dans la prise en charge des migrants en santé mentale est inséré dans de nombreux enjeux politiques qui interpellent les pratiques des professionnels à l'égard d'une patientèle dont souffrances psychiques et conditions de l'exil sont souvent entremêlées. Les consultations mettent également à l'épreuve les interprètes qui doivent se situer dans une relation de soin complexe, alors même qu'ils peuvent se retrouver face à des exigences contradictoires entre les attentes des professionnels de santé mentale et les prescriptions des associations qui les emploient. À travers le prisme de l'interprétariat, l'article interroge les divisions sociale, morale et spatiale du travail dans la prise en charge des migrants en santé mentale. Il s'appuie sur deux terrains d'enquête à Rennes et à Strasbourg, deux capitales régionales marquées par une évolution des flux migratoires, et comptant des initiatives importantes en matière de promotion de l'interprétariat professionnel.

La interpretación en el cuidado de los migrantes en salud mental se inserta en muchos asuntos políticos que desafían las prácticas de los profesionales que se preocupan por un paciente cuyo sufrimiento mental y condiciones de exilio a menudo se entrelazan. Las consultas también desafían a los intérpretes que necesitan estar en una relación de cuidado compleja, a pesar de que pueden enfrentar demandas conflictivas entre las expectativas de los profesionales de la salud mental y las prescripciones de las asociaciones que las emplean. A través del prisma de la interpretación, el artículo cuestiona las divisiones sociales, morales y espaciales del trabajo en el cuidado de los migrantes, especialmente en la salud mental. Se basa en dos sitios de encuestas en Rennes y Estrasburgo, dos capitales regionales marcadas por una evolución de los flujos migratorios, y contando importantes iniciativas en la promoción de la interpretación profesional en salud mental.

\section{INDEX}

Keywords: mental health, interpreters, professionalisation, health professionals, comparison Palabras claves: salud mental, intérpretes, profesionalización, profesionales de la salud, comparación

Mots-clés: santé mentale, interprètes, professionnalisation, professionnels de santé, comparaison

\section{AUTHORS}

\section{ANAÏK PIAN}

Sociologist, Lecturer, DynamE, University of Strasbourg-CNRS, Bât. 5, Le Patio, 22 avenue René Descartes, 67000 Strasbourg ; pian@unistra.fr 


\section{ANNE-CÉCILE HOYEZ}

Geographer, Research Fellow CNRS, SOPHIAPOL, University of Rennes-CNRS, Maison de la Recherche en Sciences Sociales, Place du Recteur Le Moal, 35043 Rennes Cedex ; annececile.hoyez@univ-rennes2.fr

\section{SIMONA TERSIGNI}

Sociologist, Lecturer, SOPHIAPOL, Université Paris Ouest Nanterre, 200 avenue de la République, 92001 Nanterre ; stersigni@parisnanterre.fr 